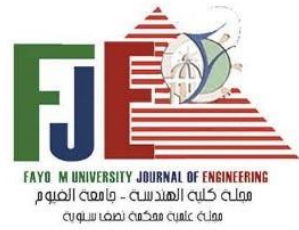

\title{
SEISMIC RESPONSE ANALYSIS ONEARTHQUAKE MOTION AT ZAFARANA WIND TURBINE FARM, EGYPT
}

\author{
${ }^{1}$ Gihan Elsayed Abelrahman \\ ${ }^{1}$ Youssef Gomaa Youssef \\ ${ }^{1}$ Mohamed Hussien Abdelaziz \\ ${ }^{1}$ Khaled Ibrahim Mohamed \\ ${ }^{1}$ Civil Engineering Department, Faculty of Engineering, Fayoum University, Egypt
}

\begin{abstract}
Zafarana wind turbine towers farm, which is located $120 \mathrm{~km}$ south of Suez on the Red Sea, lies in not only the highest wind speed zones but also the most seismically active areas. AlAqaba 1995 earthquake acceleration time history, which recorded at the Eilat station, used at the bedrock level of this research. The peak ground acceleration (PGA) of the horizontal component was almost about $0.10 \mathrm{~g}$ at the ground surface. The effect of local geologic and soil conditions on the intensity of the ground shaking discussed in this paper. Severe damage occurred due to the amplification of the earthquake motion because the site response analysis considered in the seismic response analysis. Subsurface geotechnical and geophysical (down-hole) data in eight different sites in Zafarana wind turbine farm that carried out used to assess the site response analysis on earthquake ground motion in the studied area. According to the shear wave velocities obtained from the field tests, the classification of soil at Zafarana wind turbines farm was Soil Class B and Soil Class C according to the International Building Code (IBC). Thus, the ground response analyses conducted considering the nonlinear behavior of the soil deposits using both equivalents linear and nonlinear methods. The 1-D nonlinear approach, included in DEEPSOIL v7.0, used to determine the nonlinear soil properties on seismic wave propagation through the soil column and compared to those from the equivalent linear approach, which analyzed using SHAKE 2000. The results comparison showed the same shape of spectral acceleration versus period curves for both equivalent and nonlinear analyses, and the peaks of spectral accelerations in the period range of (0.1_0.50) s. The results showed that the nonlinear amplification factors were more than the
\end{abstract}

equivalent method especially in zones that classified as Soil Class $\mathrm{C}$; however, the amplification of the ground motion was approximately the same for both approaches in zones that classified as Soil Class B. Finally, this paper concludes that the nonlinear analysis should be considered as the soil is softer and the equivalent linear analysis can be used at the zones that classified as Soil Class B or stiffer.

Keywords: Site response analysis, Equivalent linear method, nonlinear method, SHAKE 2000, DEEPSOIL v.7.0, Al-Aqaba earthquake, Wind Turbine Towers.

\section{Introduction}

Seismic waves usually travel tens to thousands of kilometers from an earthquake source to a given site, which dynamically responds to the earthquake loading, and may lead to death and destruction if there are failures in human infrastructure. In general, site response decomposed into the competing phenomena of amplification and nonlinearity. First, as seismic waves propagate toward the ground surface, they encounter softer materials with lower seismic wave velocities. By the law of conservation of energy, as the velocity of a wave decreases, its amplitude must increase. The effects of amplification are present at all ground motion levels. For large ground motions, however, a second phenomenon influences the response of a soil nonlinearity. For earthquake loadings at large shear strains, soil known to behave nonlinearly due to strain softening. Nonlinearity results in decreased stiffness and increased damping, and the net 
effect is a de-amplification of ground motion concerning linear behavior. Both amplification and nonlinearity are competing effects; existing site response models account for soil amplification and nonlinearity in various ways, leading to varying degrees of model complexity and uncertainty (Kramer, 1996).

According to Rayhani et. al. (2007), The amplification of the ground motion due to local site effects resulted in severe damage to dwellings in the Bam area during the 2003 Bam Earthquake in Iran. Subsurface geotechnical and geophysical (down-hole) data in two different sites obtained and used to estimate the local site condition on earthquake ground motion in the area. The ground response analyses had been conducted using both equivalent linear method using Shake, 2000 and nonlinear approach using FLAC 2D. The comparison of results indicated similar response spectra of the motions for both equivalent and nonlinear analyses. However, the amplification levels of nonlinear analysis were less than the equivalent linear method especially in long periods. The observed response spectra shown to be above the building code design requirements, especially at high frequencies. Anbazhagan and Sitharam, 2008, an attempt made to characterize the Bangalore Mahanagar Palike (BMP) area of about $220 \mathrm{~km}^{2}$ using the shallow geophysical method, Multichannel Analysis of Surface Wave (MASW) to produce shear-wave velocity $\left(\mathrm{V}_{\mathrm{s}}\right)$ profiles. The study area of BMP characterized as per NEHRP (National Earthquake Hazards Reduction Program) and IBC (International Building Code) site classification using an average shear wave velocity $\left(\mathrm{V}_{\mathrm{s} 30}\right)$ of $30 \mathrm{~m}$, obtained from MASW. In the study area, 58 one-dimensional (1-D) MASW survey carried out and respective velocity profiles obtained. The major part of the BMP area can be classified as "site class D", and "site class C" and a smaller part in and around Lalbagh Park is classified as" site class B". Site response study shows that due to soil condition, large modification of wave amplitudes observed resulting in higher peak ground acceleration when compared to rock level acceleration.

Equivalent linear ground response analyses conducted at four representative sites at Delhi, India to compare the free field acceleration spectra with local code of practice. To consider the uncertainty in ground motion parameters, 10 random rupture scenarios considered for each case. Spectral Analysis of Surface Waves (SASW) technique adopted to measure the in-situ shear wave velocity profile at the representative sites. Experimentally evaluated strain dependent modulus reduction and damping curves for local soils adopted. A comparison of computed response with the standard code of practice indicated that the design spectra is not able to capture site amplification due to local source. This work done by Hanumantha and G V Ramana (2009). Chandrasekaran et. al. (2012), Coimbatore, an important industrial city in Tamilnadu, has been included in seismic zone III as per the revised earthquake code (IS1893-2002). Deterministic Seismic Hazard Analysis (DSHA) carried out by identifying the faults and shears around Coimbatore. The earthquake catalogue was prepared for $350 \mathrm{~km}$ radius considering events in the past 500 years. Peak ground acceleration at bedrock level estimated. Boreholes made at the site; Singanallur and Standard Penetration Test (SPT) carried out at different depths. The shear wave velocities of soil layers are estimated using standard correlations. One dimensional equivalent linear ground response analysis carried out using SHAKE 2000. Significant amplification of motion and considerable change in frequency content of input motion observed at the ground surface. An assessment of the dynamic response of the soil to strong ground motion at the planned wind farm was undertaken. The assessment carried out in accordance with the IEC (2005) and GL (2010) standards for the design and safety requirements of wind turbines.

The effect of site response studied using the 
equivalent linear one-dimensional wave propagation analysis. The site characterization based on average soil's shear wave velocity in the upper 32 meters. The amplification factor for soil profile estimated using the transfer function method. Maximal amplification of 2.5 observed at $0.25 \mathrm{sec}$. The maximum amplifications are much lower than the natural frequency of the turbine. It means that the fundamental mode of the turbine with natural frequency $3 \mathrm{~Hz}$ not affected by maximal amplification of soil resonance (A. Cichowicz, 2012).

\section{Location And Geological Features}

The Zafarana Wind Turbine Farm is located $120 \mathrm{~km}$ south of Suez on the Red Sea, it is a location with extreme conditions and the wind turbines that installed have been specially prepared to cope with Egypt's hot desert climate, sand storms and salty air. Special seals had to be created to prevent sand from getting in to the units and rotor-blade cleaning planned for several times per year. ZWTF consists of eight zones extend along the west side of the Gulf of Suez to provide renewable energy as shown in Figure 1.The installation has been carried out under the banner of the Egyptian New and Renewable Energy Agency (NREA).

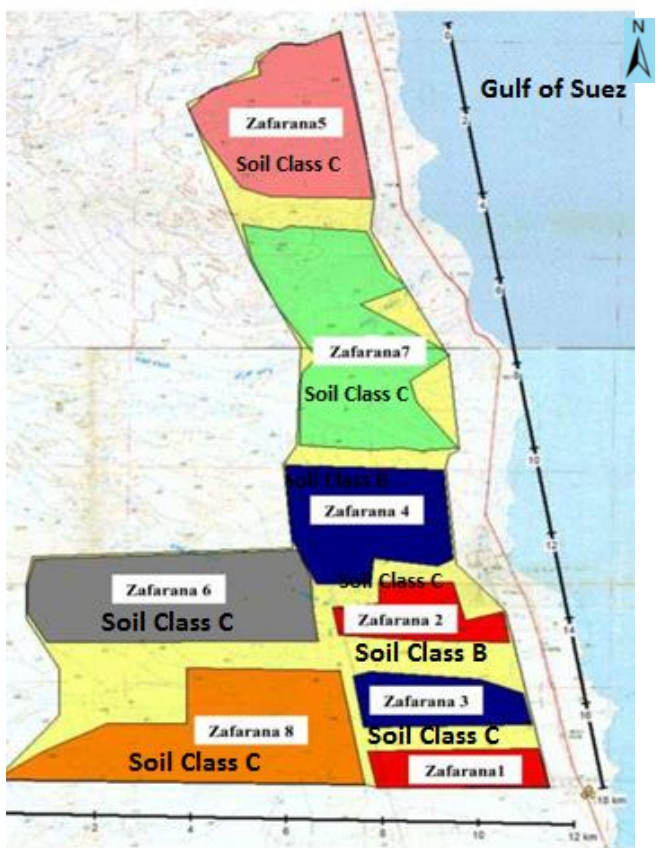

Figure 1. Location of Zafarana Wind Turbine Farm.

The characteristics of geological layer up to depth of first $30 \mathrm{~m}$ are very important in amplification of earthquake shaking. In the present study, geotechnical site investigation data collected and analyzed. These field tests indicated that, in general, the site contains five layers wadi deposit, silty sand, silty clay, sand stone and clay stone. The soil profile and physical properties of sub layers such as; shear wave velocity, unit weight, plasticity index and confining stress that used in site response analysis illustrated in soil properties section. The Surface geological map of the Zafarana region (Egyptian geological Survey, 1994) shown below in Figure 2.

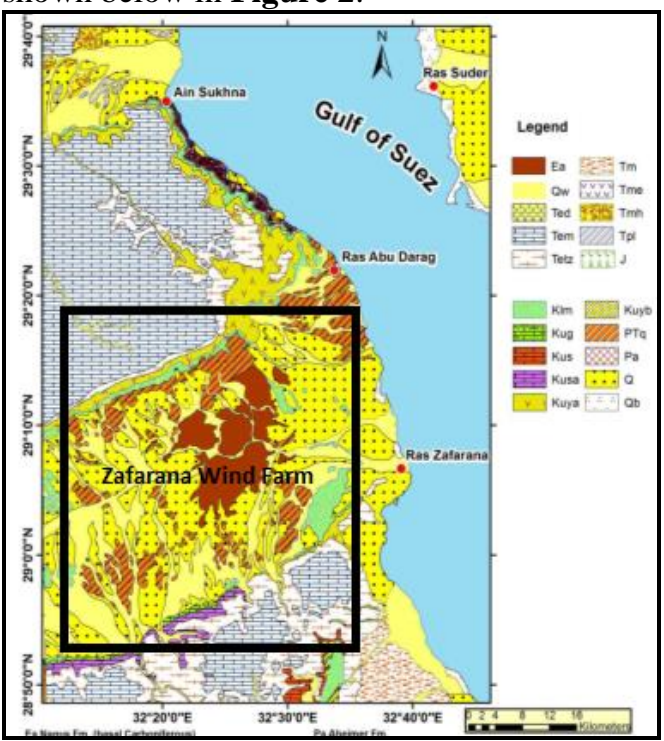

Figure 2. Surface geological map of the

Zafarana region (Egyptian Geological Survey, 1994)

\section{Geotechnical Investigation}

Geotechnical investigations were established for Zafarana sites and 698 borings were collected from previous geotechnical site investigations reports (EGEC, 2006, HAMZA ASSOSIATES, 2008 and HELAL GROUP, 2003...etc.) where the distribution of the 698 Borings have the same location of wind turbines towers cause under each wind turbine one boring was executed as shown in Figure 3. 


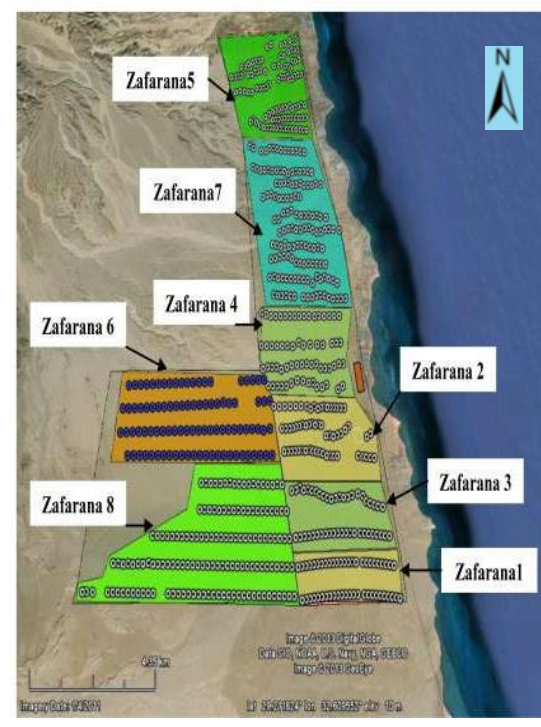

Figure 3. The Distribution of 698 Borings at Zafarana wind farms

\subsection{Geotechnical Investigation of Zafarana Wind Turbine Farms}

Based on the results of the previous site investigation and laboratory testing the soil formations encountered in the boreholes show five main formations, which are Wadi deposits, Clay, Clay stone, Sand and Sandstone. Table 1 shows the summary of the geotechnical soil properties for each soil type.

Table 1. Geotechnical soil properties for each soil type

\begin{tabular}{|c|c|c|c|c|}
\hline Soil Type & $\begin{array}{c}\gamma_{\text {bulk }} \\
\left(\mathrm{kN} / \mathrm{m}^{3}\right)\end{array}$ & $\begin{array}{c}\mathrm{q}_{\mathrm{u}} \\
(\mathrm{kPa})\end{array}$ & $\begin{array}{c}\text { Friction }^{\text {Angle }} \\
\varphi\end{array}$ & $\mathrm{E}(\mathrm{MPa})$ \\
\hline $\begin{array}{c}\text { Wadi } \\
\text { Deposit }\end{array}$ & 20 & $\ldots \ldots$ & 37 & 40 \\
\hline Clay & 22 & 100 & 25 & 30 \\
\hline $\begin{array}{c}\text { Clay } \\
\text { Stone }\end{array}$ & 23 & 500 & $\ldots \ldots$. & 90 \\
\hline $\begin{array}{c}\text { Sand } \\
\text { Sand } \\
\text { Stone }\end{array}$ & 18 & $\cdots \cdots$ & 37 & 40 \\
\hline
\end{tabular}

\subsection{Representative Boring Logs of Zafarana Wind Turbines Farms}

The 698 collected borings from previous geotechnical site investigations were analyzed to produce eight representative boring logs for the eight Zafarana wind Farms. In addition, after Abd el-aal A K et. al., 2016 using Multi Channel Analysis of Surface Wave (MCASW) to get the shear wave velocity until 30-meter-deep at Zafarana Wind Farms, the results reveal that, the obtained subsurface layers consist of four to five layers in all the seismic profiles up to a depth of $30 \mathrm{~m}$ at Zafarana site. The first layer with a thickness of (2.5-7) $\mathrm{m}$ is formed from gravels and sands and silty sand ( $\mathrm{S}$-wave velocity varies from 450 to $903 \mathrm{~m} / \mathrm{sec}$ ). The second layer with a thickness of (3.5 to 8) $\mathrm{m}$ is made up of sands and gravels and with less physical properties (S-wave velocity in the range 460 to 860 $\mathrm{m} / \mathrm{sec}$ ). The $\mathrm{S}$-wave velocities of the third layer are ranges between $520-920 \mathrm{~m} / \mathrm{sec}$ respectively, which is composed of sandstone. While the S- wave velocities of the fourth layer are ranges between $540-975 \mathrm{~m} / \mathrm{sec}$ respectively which it is composed of claystone. The fifth layer exposed only in two sites (at Zafarana 2 and Zafarana 3 only) with the $\mathrm{S}$-wave velocities ranges from 700 to 1000 $\mathrm{m} / \mathrm{sec}$.

The average shear wave velocity up to $30 \mathrm{~m}$ depth which is known as $\mathrm{V}_{\mathrm{S} 30}$ is obtained and was used to classify the site according to International Building Code (IBC-2006, the location of Zafarana 1 and from Zafarana 4 to Zafarana 8 are belong to Class $\mathrm{C}$ while the location of Zafarana 2 and Zafarana 3 are belong to Class $\mathrm{B}$. The representative boreholes, considering the geotechnical properties and geophysical studies results $\left(\mathrm{V}_{\mathrm{s} 30}\right.$ shear wave velocity versus depth), shown in Error! Reference source not found. where these boring logs were used for ground site response analysis. It noted that the following figures illustrate soil properties such as; number of soil material, unit weight, and shear wave velocity, plasticity index and 
confining pressure that used in the site response analysis.

\subsection{Local Soil Condition}

In this study, the detailed soil investigation data and geophysical as discussed in previous sections of eight representative boreholes at Zafarana wind farm as shown in Error! Reference source not found. were used for ground response analysis Subsurface profile information including unit weight, shear wave velocity at different borehole locations were used for the ground response equivalent linear analysis using SHAKE2000 (v.2) and

\begin{tabular}{|c|c|c|c|c|c|}
\hline Z\# & $\begin{array}{l}\text { Depth } \\
\text { (m) }\end{array}$ & $\begin{array}{l}\gamma \\
\mathrm{kN} / \mathrm{m}^{3}\end{array}$ & $\begin{array}{l}V_{\mathrm{S}} \\
\mathrm{m} / \mathrm{s}\end{array}$ & PI & Class \\
\hline \multirow{3}{*}{$\mathrm{Z} 1$} & $0.0-3.7$ & 20 & 468 & 0 & \multirow{3}{*}{ C } \\
\hline & $3.7-10$ & 18 & 484 & 0 & \\
\hline & $10-30$ & 22.5 & 589 & 30 & \\
\hline \multirow{3}{*}{$\mathrm{Z} 2$} & $0-7.5$ & \multirow{3}{*}{23} & 903 & 0 & \multirow{3}{*}{ B } \\
\hline & $7.5-13.5$ & & 864 & 0 & \\
\hline & $13.5-30$ & & 918 & 0 & \\
\hline \multirow{4}{*}{$\mathrm{Z3}$} & $0.0-2.5$ & \multirow{4}{*}{23} & 894 & \multirow{4}{*}{0} & \multirow{4}{*}{ B } \\
\hline & $2.5-10.5$ & & 861 & & \\
\hline & $10.5-16$ & & 983 & & \\
\hline & $16-30$ & & 993 & & \\
\hline \multirow{5}{*}{$\mathrm{Z} 4$} & $0.0-3.0$ & \multirow{4}{*}{22.5} & 629 & \multirow{4}{*}{30} & \multirow{5}{*}{ C } \\
\hline & $3.0-7.5$ & & 601 & & \\
\hline & $7.5-13.5$ & & 636 & & \\
\hline & $13.5-21$ & & 684 & & \\
\hline & $21-30$ & 23 & 717 & 0 & \\
\hline \multirow{3}{*}{ Z5 } & $0.0-3.0$ & \multirow{2}{*}{20} & 448 & 0 & \multirow{3}{*}{ C } \\
\hline & $3.0-6.0$ & & 470 & 0 & \\
\hline & $6.0-30.0$ & 18 & 531 & 0 & \\
\hline \multirow{4}{*}{ Z6 } & $0.0-3.70$ & 20 & $\frac{545}{572}$ & $\frac{0}{0}$ & \multirow{4}{*}{ C } \\
\hline & $3.70-10$ & 18 & 495 & 0 & \\
\hline & $10-18.8$ & 22.5 & 692 & 30 & \\
\hline & $18.8-30$ & 23 & 756 & 0 & \\
\hline \multirow{3}{*}{$\mathrm{Z7}$} & $0.0-10.0$ & \multirow{3}{*}{22.5} & 634 & 30 & \multirow{3}{*}{ C } \\
\hline & $10-18.8$ & & 638 & 30 & \\
\hline & $18.8-30$ & & 693 & 30 & \\
\hline \multirow{4}{*}{ Z8 } & $0.0-3.7$ & 18 & 604 & 0 & \multirow{4}{*}{$C$} \\
\hline & $3.7-10$ & \multirow{2}{*}{22.5} & 550 & 0 & \\
\hline & $10-18.8$ & & 685 & 30 & \\
\hline & $18.8-30$ & 23 & 773 & 0 & \\
\hline
\end{tabular}

nonlinear analysis using DEEPSOIL (v 7.0).

Table 2. Properties of Representative Boreholes at Zafarana Wind Farms

\section{Site Response Analysis Usıng Equivalent Linear And Nonlinear Methods}

\subsection{Ground Motion}

The ground motion of Al Aqaba Earthquake 1995 recorded at Eilat Station (Abd el-aal et al, 2015) has been used in this study. The time histories of Al Aqaba Earthquake 1995 (displacement, velocity and acceleration) are shown in the following Figure 4.a. These time histories are recorded at surface; therefore, a deconvolution analysis is performed by DEEPSOIL v.7.0 to predict the equivalent time histories at the bedrock as shown in Figure 4.b.

It is noticed that, the peak ground acceleration is $0.10 \mathrm{~g}$ at the ground surface and its equivalent at the bedrock is $0.07 \mathrm{~g}$. Moreover, the recorded peak velocity at the ground surface and its equivalent $14,10 \mathrm{~m} / \mathrm{sec}$; respectively. The recorded peak displacement at the ground surface and its equivalent 4.50, $3 \mathrm{~cm}$; respectively. Because of these outlined results, the de-amplification has occurred.
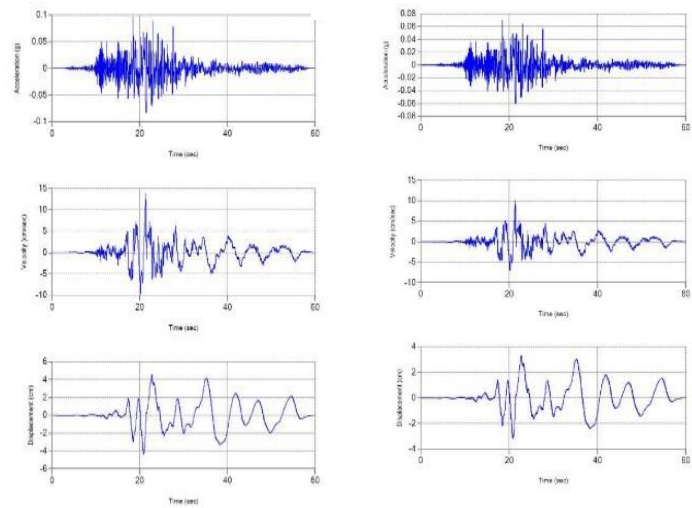

(a) 
Figure 4. The time histories of Al Aqaba Earthquake 1995 (a: at surface level, b: at bedrock level)

\subsection{Analysis Using Equivalent Linear Method by SHAKE 2000}

The response of site due to seismic wave can be estimated using three methods; linear, equivalent linear and non-linear analysis. Linear analysis is the simplest one in which it is assumed that the soil deposit consists of one uniform layer with soil stiffness either constant or varying with depth. In equivalent linear analysis, the non-linear properties of the soil are modeled in term of equivalent stressstrain properties. A non-linear analysis usually incorporates non-linear stress strain characteristics of the soil. The equivalent linear method is just an approximation method i.e., non-linear hysteretic stress-strain behavior is approximated by the modulus degradation and damping curve. The shear modulus and damping ratio curves can be defined either by defining discrete points or by defining the soil properties to be used in the hyperbolic model. The option of defining soil curves using discrete points is only available for equivalent linear analysis. Equivalent linear models defined either by soil parameters or by discrete points. Equivalent linear analysis carried out by using SHAKE, 2000 software that illustrated in the next section. A set of material curves defined in SHAKE, 2000 for modulus reduction curves and damping ratio curves for different soils. In case of sands by defining effective vertical stress, the appropriate modulus reduction curves may be arrived. In case of clays, effective vertical stress and plasticity index required to defined, for estimating modulus reduction and damping curves. In the present study, the dynamic properties of soil i.e., shear modulus reduction and damping ratio versus shear strain curves proposed by Darendeli, M.B. (2001) for sandy and clayey soil and for rock layers the shear modulus and damping ratio by Schanbel, et al., (1973) used on the eight representative boreholes at Zafarana Wind Turbine Towers Farm.

SHAKE 2000 enables the user to expect the ground movements depending on wave propagation theory, soil material properties and seismic input motion. This is done using quantitative inputs into complex mathematical calculations. One of the earliest and most successful attempts was in the early seventies when Schnabel and Lysmer (1972) published, "A computer program for conducting equivalent linear seismic response analyses for horizontally layered soil deposits" called SHAKE. This software assumes that the recurrent and circular soil behavior cane simulated using an equivalent linear model (e.g. (Kramer 1996)). From then, many upgrades and derived programs have been released. In general, the upgrades were focused on the user friendliness of the software; the fundamental part; the core algorithm was left untouched. The program is still in use widely all over the world and the upgrades are continuing in the same way.

Before running SHAKE 2000, required input parameters should be collected. These parameters in principle obtained from borehole loggings and several other geophysical investigations. In order to run the program, you need minimum input parameters as follows:

- $\quad$ Soil type.

- Thickness of the layers.

- Unit weight of the material.

- Shear modulus value of the material.

- Shear wave velocity of the material.

- Input ground motion record.

The summary of SHAKE 2000 processes illustrated in a flow chart format as shown in

Figure 5. 


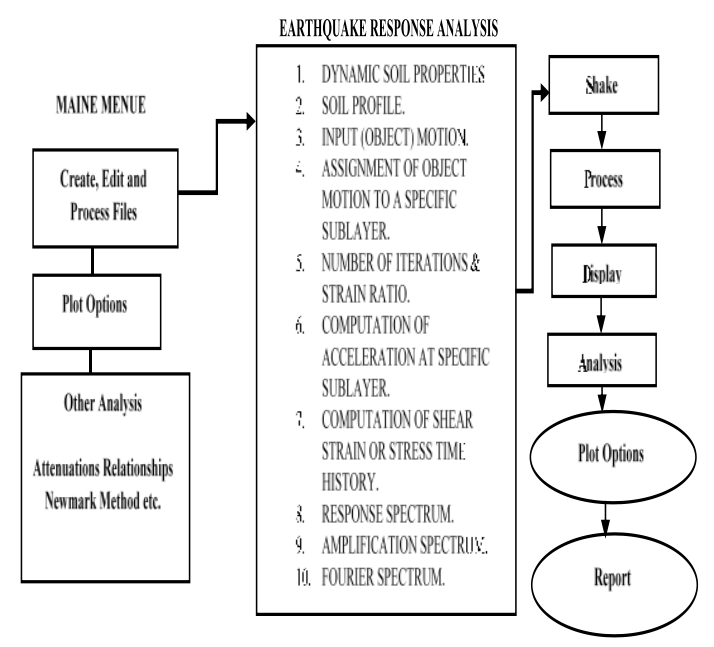

Figure 5. Shake 2000 methodology flow chart 4.3 Analysis using Nonlinear Method using DEEPSOIL v7.0

Non-linear (NL) analysis solves the equations of motions in time domain using the Newmark $\beta$ method (implicit) or the Heun's Method (explicit). DEEPSOIL v7.0 Hashash, Y.M.A et al, 2017 used to perform nonlinear site response analysis for the eight representative boreholes as shown in Error! Reference source not found. by applying the horizontal acceleration of Al Aqaba Earthquake 1995 at bedrock level and at depth $30 \mathrm{~m}$ below the surface. DEEPSOIL v7.0 incorporates the PressureDependent Modified Kondner Zelasko (MKZ) backbone model with Non-Masing hysteretic Re/Un-loading formulation (DS-NL2), and viscous damping is incorporated via the frequency independent formulation. The MKZ model parameters were selected to best fit both the specified modulus reduction and damping curves for each layer. The specified modulus reduction and damping curves used in this study were Darendeli (2001) for sand and clay layers and Schanbel, et al., (1973) for rock layers. The surface acceleration time history, the variation of peak acceleration with depth and the response spectrum at 5\% damping ratio at surface presented in the following figures for the eight Zafarana wind farms.

\section{Results of site response analysis}

The surface acceleration time history, the variation of peak ground acceleration with depth, the response spectrum at 5\% damping ratio at surface, spectral acceleration ratio (SAR) (the ratio between spectral acceleration and peak acceleration of time history) and finally the amplification spectrum between the surface layer and bedrock layers are presented below for all zones of Zafarana wind farms using SHAKE 2000 and DEEPSOIL v.7.0.

Figure 6 shows the time histories at ground surface using SHAKE 2000 from Zafarana 1 to Zafarana 8. In addition, the results for the zones of class B (Zafarana 2 and Zafarana 3) illustrate that the peak ground acceleration at surface $0.0712 \mathrm{~g}$ and $0.0702 \mathrm{~g}$ respectively. These results show that the soil stratum does not have effect during propagation of seismic waves through the soil where the peak ground acceleration at bedrock is $0.07 \mathrm{~g}$. For the remain zones of Zafarana farm (Zafarana 1 and from Zafarana 4 to Zafarana 8) that have class $\mathrm{C}$ of soil, the 
peak ground acceleration at ground surface varies from $0.072 \mathrm{~g}$ to $0.079 \mathrm{~g}$.

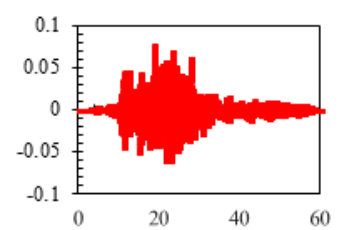

Zafarana 1
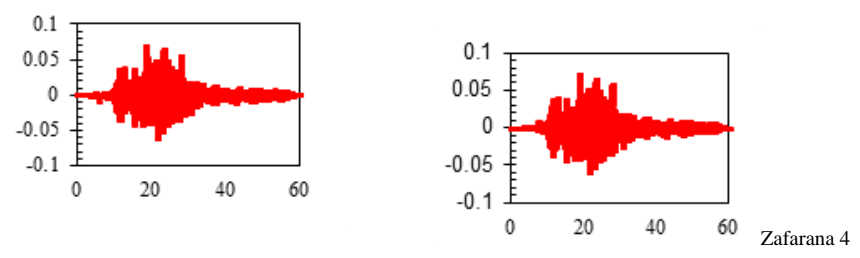

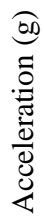
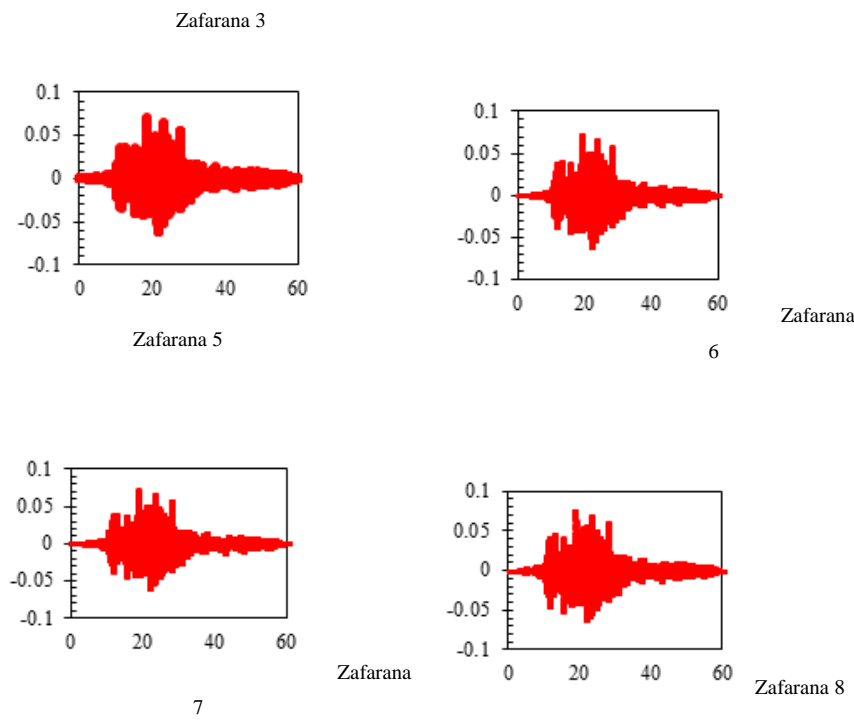

class B (Zafarana 2 and Zafarana 3) show that the peak ground accelerations at surface are $0.0728 \mathrm{~g}$ and $0.0723 \mathrm{~g}$ respectively. The results show that there isn't any amplification for earthquake motion during propagation of seismic waves through the soil. For the other zones of Zafarana farm, that have soil class C (Zafarana 1 and from Zafarana 4 to Zafarana 8), the maximum peak ground acceleration (PGA) at ground surface $0.0886 \mathrm{~g}$ at Zafarana 5 and the minimum PGA $0.0745 \mathrm{~g}$ at Zafarana 4 .

Time (Sec)

Figure 6. Acceleration time history at surface at Zafarana Farms (Shake 2000)

Wherease illustrates the time histories at ground surface at Zafarana wind farms using DEEPSOIL v7.0. Moreover, the results for soil 

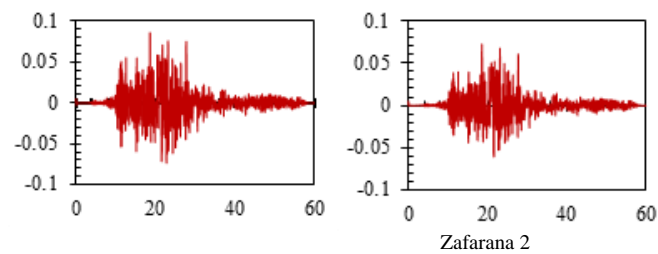

Zafarana 1
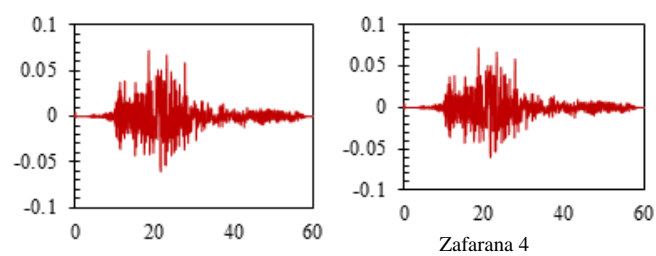

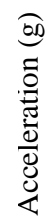
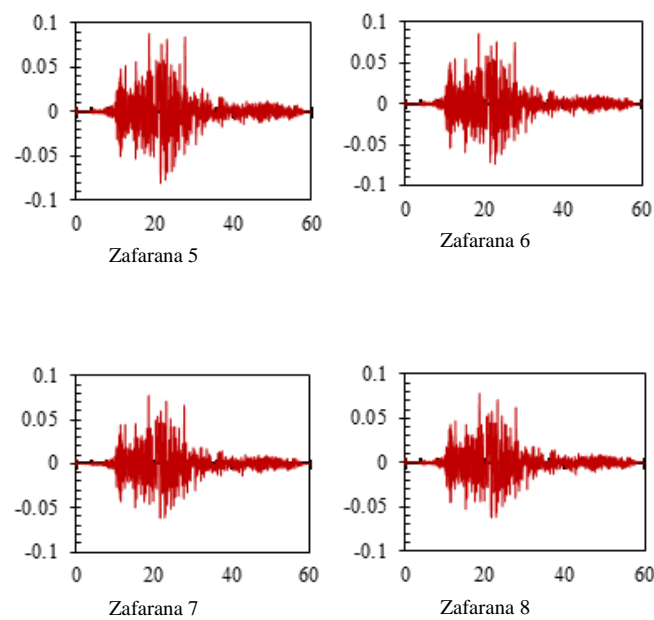

Time (Sec)

Figure 7. Acceleration time history at surface at Zafarana Farms (DEEPSOIL)

In the next section, there are the figures that present peak ground acceleration (PGA) versus depth, response spectrum (RS) and spectral acceleration ratio (SAR) for all zones at Zafarana farm using SHAKE 2000 and

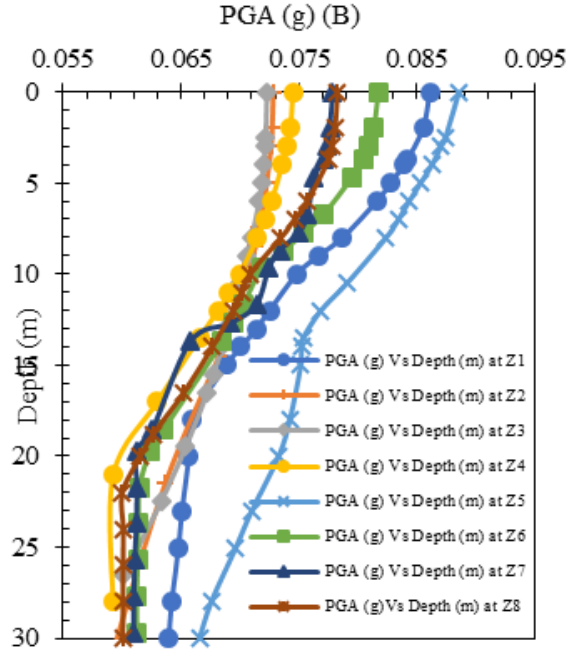

(Up) shows that Zafarana 2 and Figure 8 Zafarana 3 which related to soil class $B$ have the same shape and minimum values of peak ground acceleration with depth, however, the other zones, that have the soil class $\mathrm{C}$, have peak ground acceleration varies from $0.072 \mathrm{~g}$ to $0.079 \mathrm{~g}$ for Zafarana 7 and Zafarana 5 respectively using Shake 2000. WhereaIn

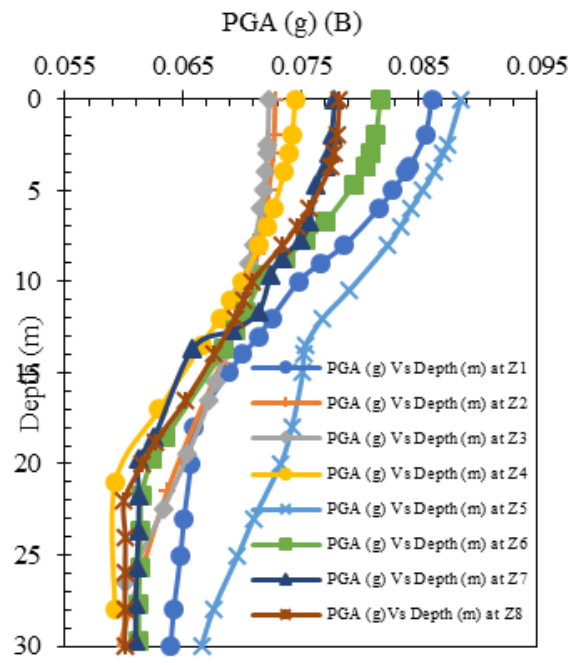


Figure 8 (Down), by using DEEPSOIL, The zones, that have a soil class B (Zafarana 2 and Zafarana 3), have the same shape and minimum values of peak ground acceleration with depth (from $0.07 \mathrm{~g}$ to $0.072 \mathrm{~g}$ ), however, the farms that classified as a soil class $\mathrm{C}$, have peak ground acceleration varies from $0.0779 \mathrm{~g}$ to $0.0886 \mathrm{~g}$ for Zafarana 7 and Zafarana 5 respectively.
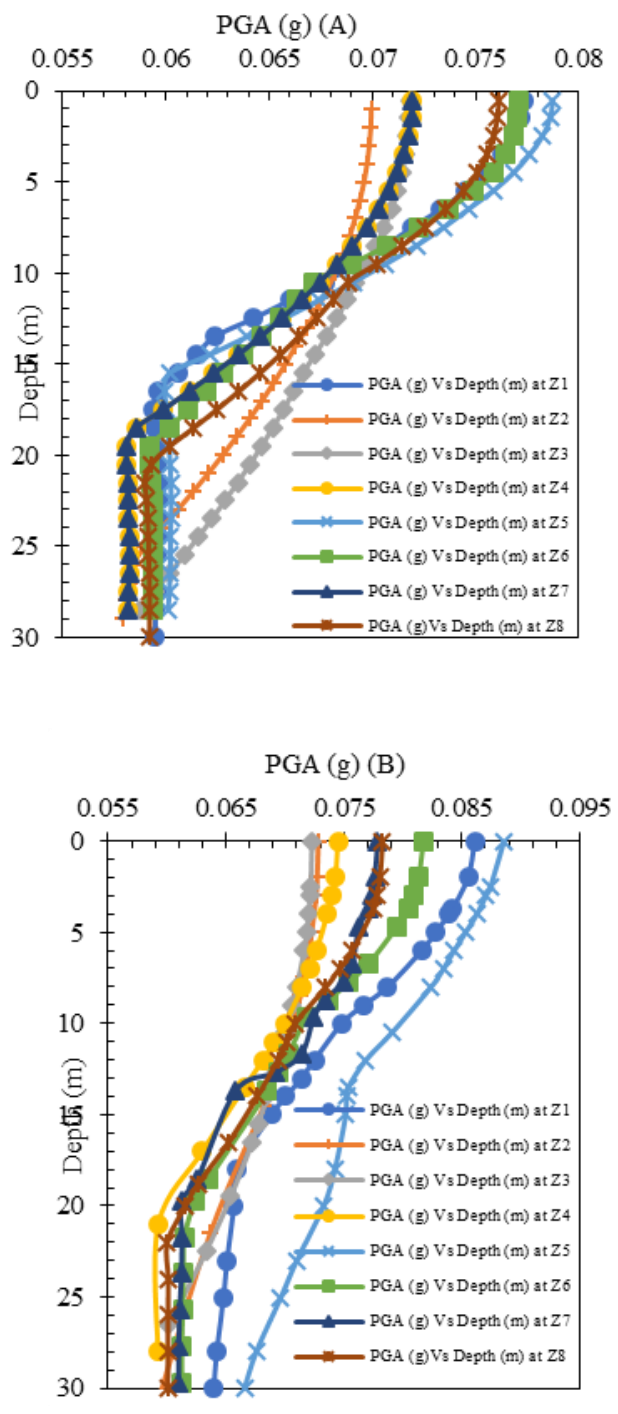

Figure 8. PGA Vs Depth for all Zafarana Zones using ((A):SHAKE, 2000, (B): DEEPSOIL)

Spectral acceleration at ground surface versus period is as one of the most important result where the structural engineer uses it in the dynamic calculations of seismic analysis, so in the spectral acceleration in $g$ units with period in Error! Reference source not found. (Up and Down) shows that the peak values of spectral acceleration for all zones lie between 0.08 to 0.50 second with values of spectral acceleration vary from $0.25 \mathrm{~g}$ to $0.29 \mathrm{~g}$ in equivalent linear analysis performed by Shake 2000, while maximum spectral acceleration $0.33 \mathrm{~g}$ at Zafarana 5 and the minimum value is $0.25 \mathrm{~g}$ at Zafarana 3 using nonlinear analysis by DEEPSOIL.

For normalization, the spectral acceleration ratio which knows as the ratio between the spectral acceleration (g) at ground surface and peak ground acceleration at ground surface versus

Figure 9. Spectral acceleration $(\mathrm{g})$ versus Period (Up: Shake 2000, Down: DEEPSOIL) period was developed and the results are shown in Error! Reference source not found. (Up and Down), the peak of spectral acceleration ratio is 4 at 0.19 second and 4.15 at 0.27 second at Zafarana 5 by Shake 2000 and DEEPSOIL respectively, however, the peak of this value for Zafarana 3 is 3.6 at period of 0.47 second and 3.090 at period of 0.17 using equivalent linear 

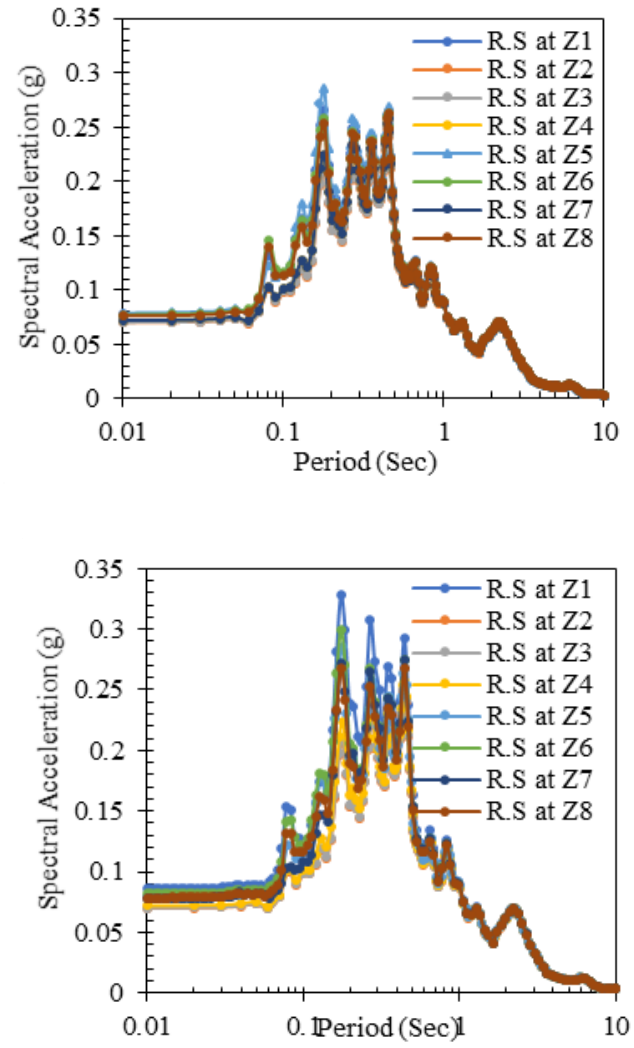

analysis (Shake2000) and nonlinear analysis (DEEPSOIL) respectively as Zafarana 5 represents the low-value of shear wave velocities with depth but Zafarana 3 has the high-value shear wave velocities versus depth.

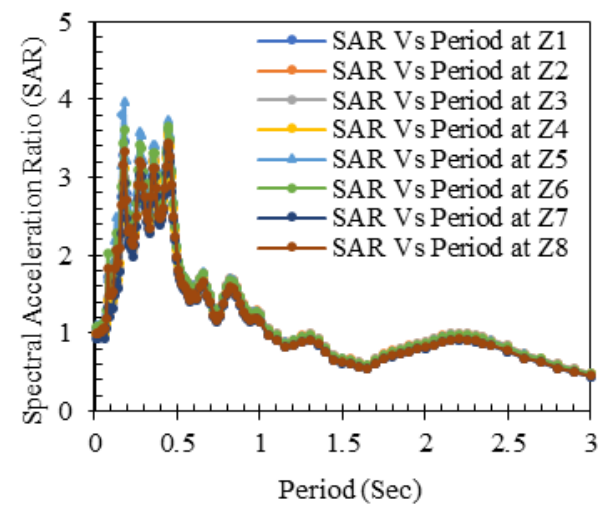

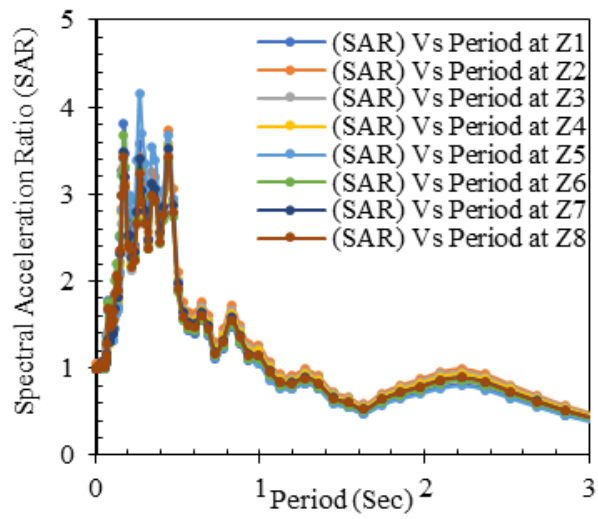

Figure 10. Spectral acceleration ratio versus period (Up: Shake 2000, Down: DEEPSOIL)

6.

\section{Comparison between Equivalent Linear and Nonlinear Methods}

Both nonlinear and equivalent linear methods used to perform ground response analyses, with quite different formulation and underlying assumptions. Consequently, it is reasonable to expect to find some differences in their results. The nonlinear method requires a reliable stress-strain or constitutive model. Field/laboratory tests are required to estimate the nonlinear model behavior. Equivalent linear method does not have the capability of incorporating stress history effects on the dynamic behavior.

A comparison for two zones at Zafarana wind farms have been performed (Zafarana 3 and Zafarana 5), that simulate Soil Class B and C respectively, to study the differences in the site response analysis results of both methods.

\subsection{Comparison Results of time histories at ground surface}

The acceleration time histories at ground surface at Zafarana 3 and Zafarana 5 are 
compared together in Figure 11 illustrates that the shape of all is the same the values of accelerations are very close together. So, the results show that the peak ground accelerations for nonlinear and equivalent linear approaches $0.072 \mathrm{~g}$ and $0.070 \mathrm{~g}$ respectively at Zafarana 3 (soil class B). Thus, the amplification factors are 1.03 for nonlinear method and 1.00 for equivalent linear. However, at Zafarana 5 (soil class C), there is a difference where peak ground acceleration at ground surface is $0.0886 \mathrm{~g}$ and $0.072 \mathrm{~g}$ for nonlinear and equivalent linear methods respectively. Therefore, the amplification factor is 1.26 using DEEPSOIL v7.0 and 1.02 using SHAKE, 2000.
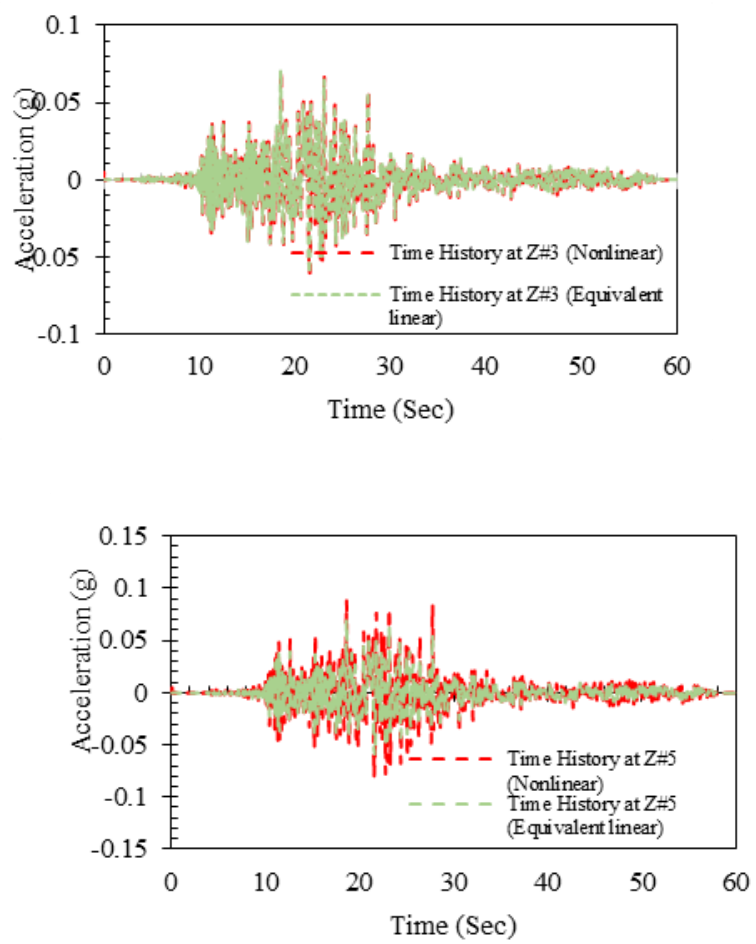

Figure 11. Acceleration time histories at ground surface using Shake,2000 and

DEEPSOIL v7.0

(a) at Zafarana 3 (Soil Class B)

(b) at Zafarana 5 (Soil Class C)

\subsection{Comparison of Peak Ground Acceleration versus Depth}

Figure 12 shows a comparison between the peak acceleration with depth between SHAKE and DEEPSOIL at Zafarana 3, the peak acceleration at surface computed by SHAKE is always similar or less than the peak acceleration computed by DEEPSOIL. On the other hand, at Zafarana 5 the peak ground acceleration along the depth of soil analyzed using DEEPSOIL is more than computed using SHAKE, 2000.

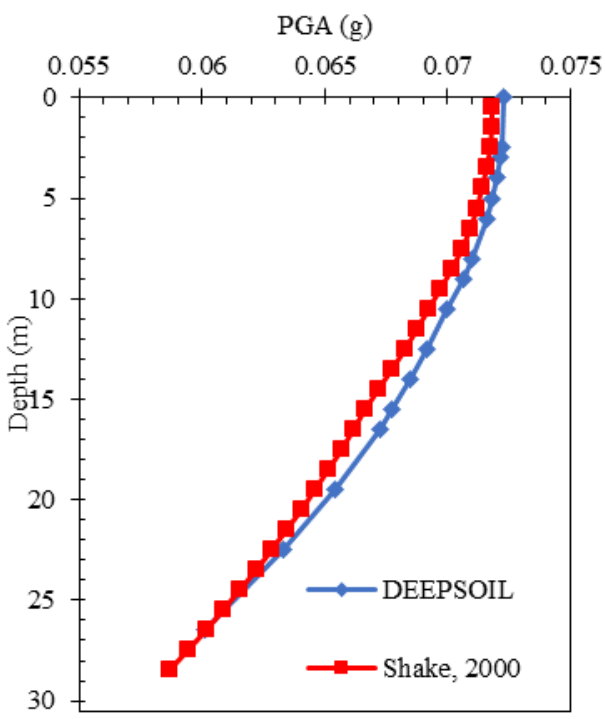



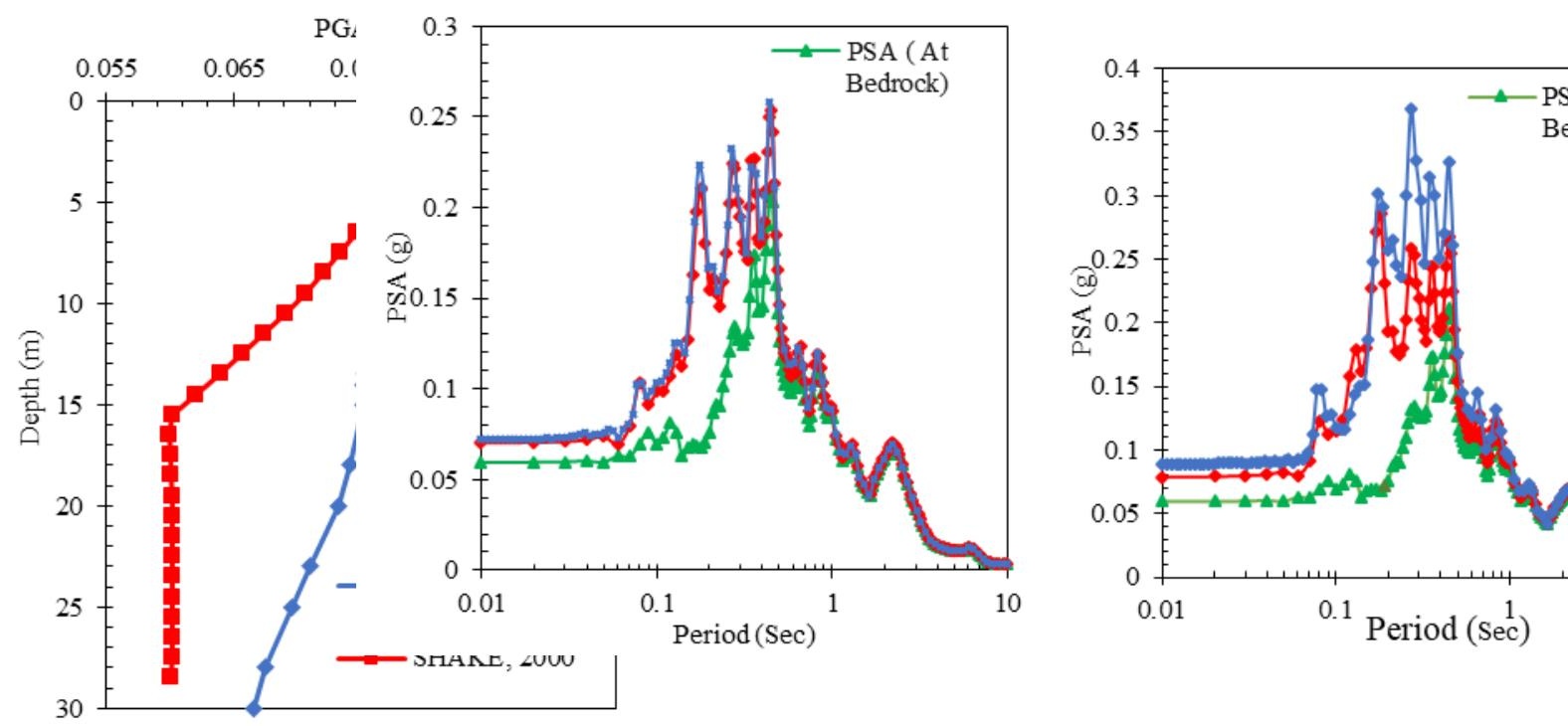

Figure 12. PGA Vs Depth using DEEPSOIL and SHAKE, 2000 (Up: at Zafarana 3, Down: at Zafarana 5)

\subsection{Comparison of Spectral Acceleration versus Period}

The comparison of results indicated similar peak response spectra in terms of peak frequency for both equivalent and nonlinear analysis with a small increase in nonlinear method at Zafarana 3 (Soil Class B), however, the amplification levels of nonlinear analysis are more than the equivalent linear method at Zafarana 5(Soil Class C) especially at period from 0.20 to 0.50 seconds as shown in Figure 13.
Figure 13. Spectral Acceleration at bedrock and ground surface. Up: at Zafarana (Soil Class B) and Down: at Zafarana 5 (Soil Class C) Using DEEPSOIL and SHAKE,2000

\section{Conclusion}

The acceleration time histories have the same shape and approximately equal values at Zafarana 3 (soil class B), however, there is a little difference and high values in nonlinear analysis at Zafarana 5 (soil class C). Moreover, the peak ground acceleration (PGA) along the depth of soil has not any big difference of both methods and the little increase been in nonlinear analysis using DEEPSOIL at Zafarana 3. On the other side, at Zafarana 5, which its soil is weaker than Zafarana 3, the nonlinear analysis has more values of peak ground acceleration with depth and the amplification factor is 1.23 . The spectral acceleration, in both nonlinear and equivalent 
linear approaches, showed peaks in the period rang 0.16 to 0.50 seconds. The peaks spectral accelerations of nonlinear analysis were approximately equal to equivalent linear at Zafarana 3 and the maximum value was $0.26 \mathrm{~g}$ at period of $0.44 \mathrm{~s}$, however, the maximum spectral acceleration at Zafarana 5 was $0.36 \mathrm{~g}$ at $0.27 \mathrm{~s}$ period in nonlinear method that is higher than equivalent linear approach that has maximum spectral acceleration $0.29 \mathrm{~g}$ at $0.18 \mathrm{~s}$ period.

To conclude based on the previous comprehensive study, as the soil is softer; the nonlinear method shows higher amplification and spectral acceleration compare to the equivalent linear analysis. In addition, as the soil is stiffer, the nonlinear and equivalent linear approaches have the same results and the amplification factors approximately equal. Therefore, it is better to use real nonlinear approach in critical projects such wind farms where wind turbine towers very sensitive structures to low frequencies.

\section{Acknowledgments}

The authors would like to express their gratitude to all the organizations, corporations, and individuals who contributed to this research. The research is funded by the USEgypt Cooperative Research Project, entitled: "Seismic Risk Assessment of Wind Turbine Towers in Zafarana Wind Farm, Egypt" (NSF grant No. OISE 1445712).

\section{References}

Abd el-aal, A. K., Yuji. Y., Kamal, H., Abdelrahman, K. (2016). Implementation of integrated multi-channel analysis of surface waves and waveform inversion techniques for seismic hazard estimation. Arab Geoscience Journal, 9:322. doi: 10.1007/s12517-016-2329-6.

Abd el-aal, A. K., Kamal, H., Abdelhay, M. \& Elzahaby, K. (2015). Probabilistic and stochastic seismic hazard assessement for wind turbine tower sites in zafarana wind farm, gulf of Suez, Egypt. Bulletin Engineering Geology Environment Journal, 74:1225-1241. doi: 10.1007/s10064-0150717-x

Cichowicz , A. (2012). Assessment of the Dynamic Response of the Soil to Strong Ground Motion at a Wind Farm, 15th Wind Conference Earthquake Engineering, LISBOA 2012.

Darendeli, M. B. (2001). Development of a new family of normalized modulus reduction and material damping curves, Ph.D. Thesis, Univ. of Texas at Austin, Austin, Texas, United States.

GL (2010), GERMANISCHER LLOYD, Guide for the Certification of Wind Turbines, Germany.

Hanumantha \& Ramana , G. V. (2009). Site Specific Ground Response Analyses at Delhi, India. Earthquake Journal of Geotechnical Engineering, Vol 14, Bund. D.

Hashash, Y.M.A., Musgrove, M.I., Harmon, J.A., Ilhan, O., Groholski, D.R., Phillips, C.A., and Park,D. (2017) "DEEPSOIL 7.0, User Manual".

Hashash, Y. M. A., and D. Park (2001) Nonlinear one-dimensional seismic ground motion propagation in the Mississippi embayment. Eng. Geol. 62, 185-206.

Hough, S. E., Friberg, P. A., Busby, R., Field, E. F., Jacob, K. H., \& Borcherdt, R. D. (1990). Sediment-induced amplification and the collapse of the Nimitz freeway, Nature $344,853-855$. 
Idriss, I. M., and J. I. Sun (1992) SHAKE91: A computer program for conducting equivalent linear seismic response analyses of horizontally layered soil deposits, User's Manual, University of California, Davis, California, $37 \mathrm{pp}$.

International Building Code IBC. (2006). Site classification using the average shear wave velocity in the upper $30 \mathrm{~m}$ thickness.

International Code Council (ICC). (2009). International Building Code (IBC) 2009, Falls Church, Virginia, 680 pp.

Ishibashi, I., \& X. Zhang. (1993). Unified dynamic shear moduli and damping ratios of sand and clay. Soils Found. 33, 182-191.

IEC. (2005). Wind Turbines - Part 1 Design Requirements. IEC 61400-1. Geneva. 19.

Kramer, S. L. (1996) Geotechnical Earthquake Engineering, Prentice Hall.

Masing, G. (1926). Eigenspannungen and verfertigung beim messing. Proc. 2nd International Congress on Applied Mechanics, Zurich, Switzerland.

Rayhani, M. H. T., El Naggar, M. H., Tabatabaei, S. H. (2007). Nonlinear Analysis of Local Site Effects on Seismic Ground Response in the Bam Earthquake. Geotech Geol Eng, DOI 10.1007/s10706007-9149-0

SHAKE2000 'A Computer Program for the 1-D analysis of Geotechnical Earthquake Engineering problems." Geomotions, inc.

Schnabel, P. B., J. Lysmer, \& H. B. Seed. (1972). SHAKE: A computer program for earthquake response analysis of horizontally layered sites, Report UCB/EERC-72/12, Earthquake Engineering Research Center, Univ. of California, Berkeley, 102 pp.

Sitharam, Anbazhagan. (2008). Site Characterization and Site Response Studies Using Shear Wave Velocity, JSEE: Summer 2008, Vol. 10, No. 2, page 53-67

Chandrasekaran , S.S., Bharadwaja , G. S., Bharathi, P. \& Dutt, H. H. (2012). Seismic Ground Response Analysis for a Site in Coimbatore, Indian Society of Earthquake Technology, Department of Earthquake Engineering building, IIT Roorkee, Roorkee, Paper No. A005
Stewart, J.P., A. O. Kwok, Y. M A. Hashash, N. Matasovic, R. Pyke, Z. Wang, \& Z. Yang. (2008). Benchmarking of nonlinear geotechnical ground response analysis procedures, PEER Report 2008/04, Pacific Earthquake Engineering Research Center, Univ. of California, Berkeley, California, $205 \mathrm{pp}$. 


\section{تحليل رد الفعل الزلزالي على حركة الزلزال بمزرعة الزعفرانة لتوربينات الرياح في مصر}

\section{ملخص البحث}

تقع مرزعة أبراج توربينات الرياح البرية بالزعفرانة على بعد 120 كم من خليج السويس على شاطئ البحر الأحمر. الجدير

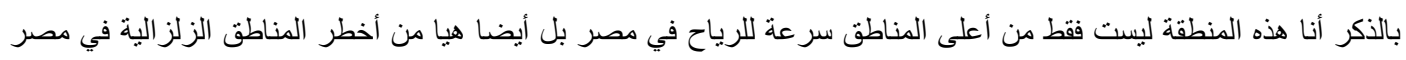

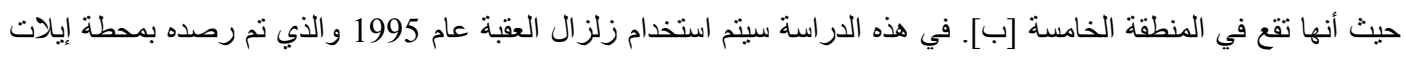

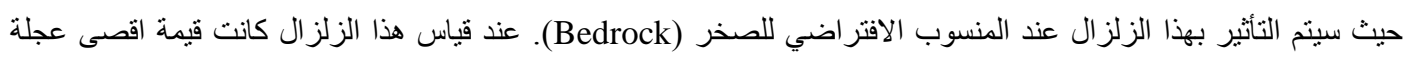

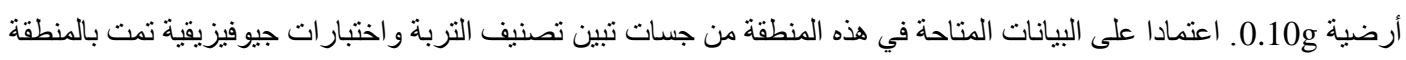

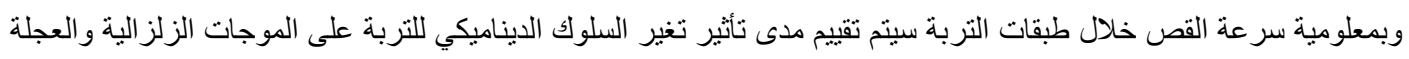

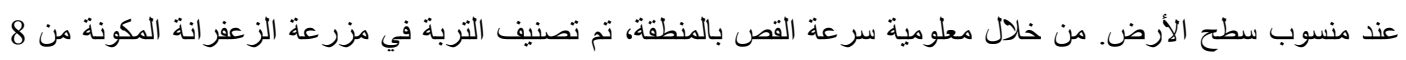

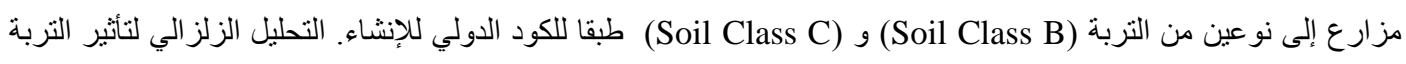

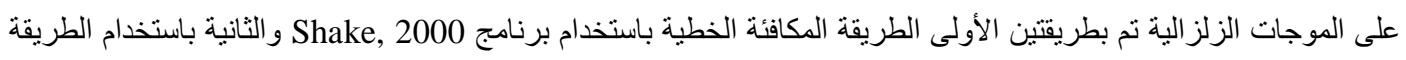

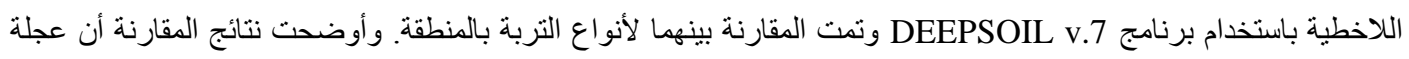

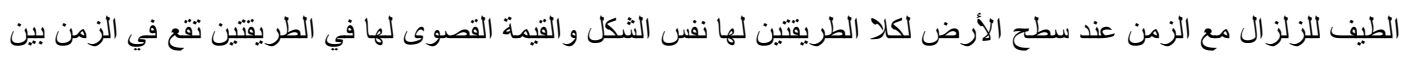

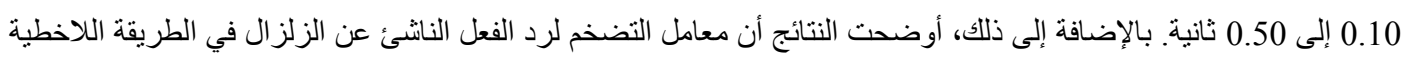

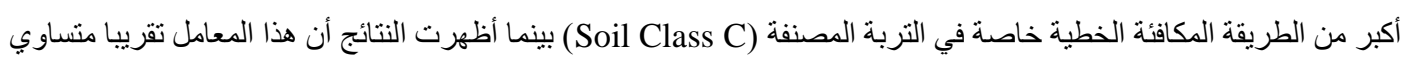

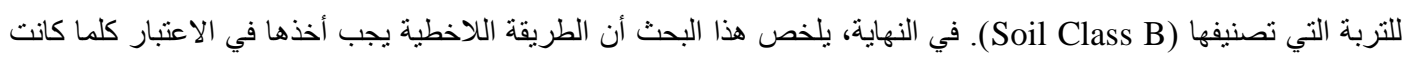

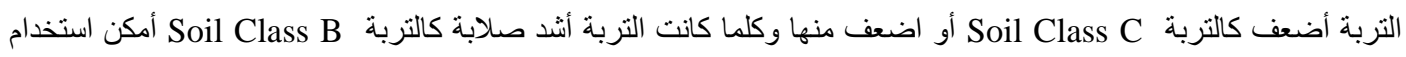

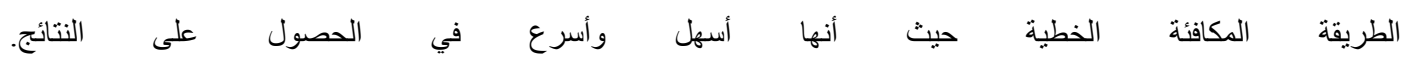

